\title{
Ülke İmajının Yabancı Ürün Satın Alma İstekliliği Üzerindeki Etkisinde Tüketici Etnosentrizmi ve Ürün Yargilarının Rolü
}

The Role of Consumer Ethnocentrism and Product Judgments in the Effect of Country Image on Willingness to Buy Foreign Products

Öz

Teknolojinin gelişmesiyle ülkeler arasında etkileşim artmış ve uluslararası işletmeler pazarda daha yaygin hale gelmiştir. Bu işletmelerin ulusal işletmelerle rekabet halinde olması tüketicileri satın alma kararı verirken ikilemde brrakabilmektedir. Kimi tüketiciler kalite, fiyat ve fayda gibi özelliklere vurgu yaparak yabanct işletmelere daha ılımlı bakabilirken, kimi tüketiciler yabancl ürün satın almanın ülkenin gelişimini olumsuz etkilediği düşüncesiyle yerli ürünlerin öncelikli olarak tercih edilmesi gerektiğini savunmaktadır. Bu araştırmanın temel amacı menşe ülke imajının etnosentrizm, ürün yargısı ve yabancı ürün satın alma istekliliği üzerindeki etkilerini incelemektir. Bu amaçla 396 katılımcıya anket uygulanmıştır. Elde edilen veriler SPSS ve SPSS Process makrosu ile analize tabi tutulmuştur. Analiz sonucunda ülke imajının ürün yargısı ve satın alma istekliliği üzerinde pozitif, tüketici etnosentrizmi üzerinde negatif etkiye sahip olduğu; etnosentrizmin satın alma istekliliği üzerinde negatif, ürün yargllarının pozitif etkiye sahip olduğu; etnosentrizm ve ürün yargllarını ülke imajı ve satın alma istekliliği arasındaki ilişkide aracılık rolü bulunduğu sonuçlarına ulaşılmıştır.

\footnotetext{
Abstract

With the development of technology, the interaction between nations has increased and international businesses have become more common in the market. The fact that these businesses are in competition with national businesses may leave consumers in a dilemma when making a purchase decision. While some consumers are more moderate towards foreign businesses by emphasizing features such as quality, price and benefit, some consumers argue that domestic products should be preferred primarily, considering that purchasing foreign products negatively affects the development of the country. The main purpose of this research is to examine the effects of country of origin image on ethnocentrism, product judgment and willingness to purchase foreign products. For this purpose, a questionnaire was applied to 396 participants. The obtained data were

\begin{abstract}
Keywords
Country Image, Consumer Ethnocentrism, Product Judgments, Willingness to Buy Foreign Products.
\end{abstract}

JEL: M31, D91

Submitted: $\quad 14$ / 09 / 2021 Accepted: $17 / 11 / 2021$ analyzed with SPSS and SPSS Process macro. As a result of the analysis, it was concluded that country image has a positive effect on product judgment and willingness to buy foreign products, and a negative effect on consumer ethnocentrism; that consumer ethnocentrism has a negative effect on willingness to buy foreign products and a positive effect on product judgments; that ethnocentrism and product judgments have a mediating role in the relationship between country image and willingness to buy foreign products
}

\begin{abstract}
Ali Köroğlu
Öğr. Gör., Tokat Gaziosmanpaşa Üniversitesi, Adalet MYO, Büro Hizmetleri ve Sekreterlik, alikoroglu5461@gmail.com, Orcid No: https://orcid.org/0000-00034021-6300
\end{abstract}

\author{
Salih Yıldız \\ Doç. Dr., Gümüşhane Üniversitesi, İBF, \\ İsletme Bölümü, \\ salihyildiz@yahoo.com, \\ Orcid No: https://orcid.org/0000-0002- \\ 1002-5960
}

\section{Article Type / Makale Türü \\ Research Article / Araştırma Makalesi

\begin{abstract}
Anahtar Kelimeler
Ülke İmajı, Tüketici Etnosentrizmi, Ürün Yargıları, Yabancı Ürün Satın Alma Ístekliliği.
\end{abstract}

\section{Giriş}

Günümüzde teknolojinin gelişimine paralel olarak ulusların birbirleriyle etkileşimlerinin artması, çok uluslu şirketlerin varlı̆̆ının artmasına, dolayısıyla birçok yabancı menşeli markanın farklı ülkelerde tüketicilere sunulmasına zemin hazırlamıştır. Yabancı menşeli markaların ulus sınırları içinde satışa sunulması tüketici davranışlarında da bazı farklılıkları beraberinde getirmiştir. 
Kalite, fiyat ve verimlilik faktörlerini ön planda tutarak bu markalara 1lımlı yaklaşan tüketiciler olduğu gibi bu markalara karşı olumsuz refleks geliştiren tüketicilerin de mevcudiyeti artmıştır.

Tüketiciler bu markaların ürünlerini satın alma kararı verirken bu markaların hangi ülkeye ait olduğu, bu ülkelerle kendi ülkelerinin ilişkileri, menşe ülkenin imajı vb. faktörleri de dikkate almaktadırlar. Menşe ülkenin gelişmişlik seviyesi, halkının tutumu, eğitim seviyesi, gelir düzeyi, yaşam standardı gibi üründen ziyade ülkeyle ilgili özellikler de tüketiciler üzerinde etkili olabilmektedir. Bu özellikler ayrıca tüketicilerin yabancı menşeli ürünlere yönelik etnosentrik eğilimlerini de hafifletebilmektedir. Etnosentrizm kısaca ırk merkezcilik olarak tanımlanırken, tüketici etnosentrizmi bireylerin yabancı menşeli ürünler yerine kendi ülkesine ait markaların ürünlerini tercih etmesi, yerli marka ürünleri satın almanın daha ahlaki olduğuna inanması anlamına gelmektedir. Tüketici etnosentrizmi, istenen imaja sahip ülkelerin ürünlerine yönelik daha hafif olabilirken, istenmeyen imaja sahip ülkelerin ürünlerinde daha şiddetli kendini gösterebilmektedir. Ayrıca birçok ülkede tüketicileri etnosentrik eğilimler geliştirmeye yönelik çabalar da artmıştır (Göktaş, 2019: 271). Örneğin İsrail'in Filistin halkına ve Çin'in Doğu Türkistan'da yaşayan Türklere yönelik gerçekleştirdiği şiddet olayları neticesinde Türk ve Müslümanların çoğunlukta olduğu birçok ülkede bu ülkelerin ürünlerine yönelik boykot eylemleri gerçekleştirilmektedir. Ancak ABD ve Almanya gibi ülkelerle diplomatik sorunlar yaşandığında bu tarz tepkilere çok fazla rastlanmamaktadır. Bu doğrultuda menşe ülke imajının markaların yabancı pazarlarda etnosentrik tutumlara maruziyetini hafiflettiği söylenebilir.

Ülkenin sahip olduğu imaj etnosentrizm üzerinde olumsuz bir etkiye sahipken, ürün yargis1 üzerinde tam tersi bir etki yapabilmektedir. Tüketicilerde gelişmiş ülkelere ait ürünlerin de kaliteli olacağına dair bir alg1 oluşabilmektedir. Örneğin Almanya'nın teknolojik gelişmişliği, halkının eğitim düzey, refah seviyesi vb. faktörler Almanya menşeli ürünlerin de kaliteli olacağına yönelik toplumda bir algı oluşturmaktadır. Çin ve Hindistan gibi ülkelerde ise bunun tam tersi bir durum söz konusudur. Örneğin Hindistan bilişim sektöründe çok önemli bir yere sahip duruma gelmişken, bu ülkenin ürünlerine yönelik olumlu değerlendirmeler aynı derecede artmamaktadır. Günümüzde her ne kadar Çin bu algıyı yıkacak gelişmeler kaydetmiş olsa da geçmişte ürettiği ucuz ve kalitesiz ürünler, Çin malı (kalitesiz ve ucuz malları tanımlamak için kullanılmaktadır) kavramının doğmasina sebep olmuştur.

Ülkelerin imajıyla ilişkili olan etnosentrizm ve ürün yargısı yabancı ürün satın alma istekliliğini etkileyebilir mi?" sorusu bu araştırmanın temel problemini oluşturmaktadır. Bu çalışma ülke imajı, etnosentrizm ve ürün yargısının yabancı ürün satın alma istekliliği üzerindeki etkilerini araştırmak amacıyla Türk tüketiciler üzerinde gerçekleştirilmiştir. Araştırma üç bölümden oluşmakta olup, birinci bölümde ülke imajı ve etnosentrizmle ilgili kavramsal çerçeve ve literatür taraması, ikinci bölümde araştırma yöntemi ve bulgular, son bölümde ise sonuç ve öneriler kısmı yer almaktadır.

Literatür incelendiğinde tüketici etnosentrizmi, ürün yargıları ve satın alma istekliliği arasındaki ilişkileri inceleyen pek çok araştırmayla karşılaşılmaktadır. Ancak ülke imajının bu değişkenler üzerindeki etkisini inceleyen çok fazla çalışma bulunmamaktadır. Ayrıca tüketici etnosentrizmi ve ürün yargılarının ülke imajı ile satın alma istekliliği arasındaki ilişkide aracılık rolünü inceleyen çalışmaya da rastlanmamıştır. Ülke imajının tüketici etnosentrizmi, ürün yargıları ve satın alma istekliliği üzerindeki etkilerini ve tüketici etnosentrizmi ile ürün yargılarının ülke imajının satın alma istekliliği üzerindeki etkisinde aracılık rollerini inceleyen bu çalışmanın literatüre katkı sağlayacağı düşünülmektedir.

\section{Kavramsal Çerçeve}

\section{1. Ülke İmaj1}

Her kurum, nesne ya da kişi ister bilinçli bir şekilde yönetilmiş, ister kendiliğinden gelişmiş olsun çevresi tarafindan algılanan bir imaja sahiptir. Dolayısıyla imaj kavramı genel olarak bir nesnenin, kuruluşun ya da kişinin algılanması şeklinde tanımlanabilir. Diğer bir ifadeyle imaj, çeşitli kaynaklardan edinilen izlenimler sonucunda oluşmaktadır (Keskin ve Yıldız, 2010:241). Kurumlar ve nesneler gibi ülkeler de çevreleri tarafından algılanan bir imaja sahiptir (Ateşoğlu ve Türker, 2013: 112). Ülke imajı konusunda ilk çalışma 1970 yılında Nagashima tarafından yapılmış 
ve devamında farklı araştırmacılar tarafından da kavram yoğun olarak çalışılmıştır (Ülker Demirel, 2020: 1226). Bu çalışmalarda ülke imajı farklı araştırmacılar tarafında farklı şekillerde tanımlanmıştır. Bu çalışmalarda ülke imajı; ülkenin genel imajı, ürün-ülke imajı ve ürün imajı olarak üç farklı kapsamda tanımlanmaktadır (Roth ve Diamantopoulos, 2009: 727). Ülke imajının ülkenin genel imajını ön planda tutarak tanımlayan çalışmalar, ülke imajının ekonomik ve politik olgunluk, sunulan ürünler, gelenekler, endüstrileşme, tarihi olaylar ve ilişkiler gibi veriler tarafından oluşturulduğunu (Bannister ve Saunders, 1978: 562); insanların ülkeyle ilgili tüm tanımlayıc1, bilgilendirici ve çıkarımsal (Martin ve Eroğlu, 1993: 193) fikirlerinin, inançlarının ve izlenimlerinin toplamı olduğunu (Kotler vd., 1993: 141) yani ülke ile ilgili genel tutumları yansıttığımı belirtmektedir (Aydın ve Biçer, 2017: 149). Ürün ülke imajı ise "bir ürün hakkında satıcıların ve müşterilerin ne düşündüğüdür" şeklinde tanımlanmaktadır (Papadopulos ve Heslop, 2003: 404). Ülke imajını ürün imajı kapsamında tanımlayanlar ise ülke imajının bir ülkede üretilen ürünlerin kalitesi hakkında tüketicilerin sahip olduğu genel algı olduğunu belirtmektedir (Han, 1989: 222).

Ülke imajı ülkede üretilen ürünler, ülke halkının özellikleri, ülkenin tarihi, gelenekleri, ekonomisi sosyal ve politik yapısı gibi pek çok faktörün etkisiyle oluşmaktadır (Ateşoğlu ve Türker, 2013: 116). Bu nedenle ülke imajının pek çok farklı bileşeni veya boyutu olduğu ifade edilebilir. Yapılan çeşitli çalışmalarda da ülke imajı farklı boyutlarda ele alınmıştır. Park vd. (2014: 55) çalışmalarında ülke imajının politik, kültürel, spor, ekonomik ve teknolojik olmak üzere beş boyuttan oluştuğunu ifade etmişlerdir. Lala vd., (2009: 63) ülke imajının ekonomik koşullar, iş kültürü, emek, çevre, siyasi yapı, mesleki eğitim ve çatışma olmak üzere yedi boyuttan oluştuğunu belirtmektedir. Wang vd. (2012: 1046) ülke imajını bilişsel ve duygusal algılar olarak iki boyutta incelerken, Laroche vd. (2005: 100) çaba/gayret boyutunu da ekleyerek ülke imajını üç boyutta incelemişlerdir.

Satın alma kararlarının önemli bir belirleyicisi olan ülke imajı çok karmaşık unsurlar içermektedir. Ülke imajı bireylerin zihninde henüz küçük yaşlarda aileden, okuldan ve kitaplardan edindiği bilgiler doğrultusunda şekillenmeye başlar. Ülke hakkındaki toplumsal yargılar bu süreçte bireyin zihninde yer edinmeye başlar. Özellikle tarihsel olaylara dayalı olarak oluşan yargılar yüz yıllar boyunca fazla değişime uğramayabilir (Özenç, 2002: 39; Öter ve Özdoğan, 2005: 130). Örneğin Azerbaycanlı Türklerin Ermenistan'a yönelik algıları tarihi olaylar çerçevesinde şekillenmiş ve uzun yıllar değişikliğe uğramamıştır. Bu duruma örnek olarak Türkiye-Yunanistan, Arap Ülkeleri-İsrail, Küba-ABD gibi örnekler de verilebilir. Ancak günümüzde bireyler bilgi ve iletişim teknolojilerindeki gelişmeler nedeniyle birçok farklı kaynaktan bilgi edinebilmekte ve bu bilgiler doğrultusunda ülkelere yönelik imaj algısı değişebilmektedir (Ateşoğlu ve Türker, 2013: 116). Bu nedenle ülke imajı sadece ülkenin sahip olduğu genel imajla sınırlı olmaktan ziyade ülkenin ürettiği ürünlere, üretim ve pazarlama gücüne, zayıflıklarına yönelik algılara da dayanmaktadır (Koubaa, 2008: 140). Dolayısıyla ülkelerin ürünlerini, şirketlerini, markalarını ve daha fazlasını kapsayan özel bir imaj türü olan ülke imajı (Jenes, 2008: 67) birçok faktörün etkisiyle oluşmaktadır. Bu faktörler ülkenin ithalat-ihracat düzeyi veya ülkede kişi başına düşen milli gelir gibi ekonomik faktörler olabilirken turistik çekicilik, müzik, yerel gelenekler, milliyetçi tutumlar, siyasi ve askeri düşmanlık gibi faktörler de olabilmektedir. Ayrıca sinema, televizyon, gazeteler ve reklamlar da dışarıdaki insanların ülke hakkındaki algılarında etkili olmaktadır (Kotler vd., 2000: 55). Ülkelerin ürettikleri ürünler hakkında geçmiş satın alma deneyimleri, ürünlerle ilgili eski izlenimler ve ülke ürünlerine yönelik olumlu veya olumsuz yargılar da ülke imajını etkileyen faktörler arasındadır (Cengiz, 2009: 157).

Ülke imajı ürün ve markaların cazibesini artırmaktadır. Örneğin Gucci markası deri vb. ürünlerinin pazarlanmasında İtalya'nın bu kategorideki imajından faydalanmaktadır (Papadopoulos, 2004: 38). Türk tüketicilerin Japonya, ABD ve Batı Avrupa ülkelerine yönelik algısı bu ülkelerden gelen ürünlere yönelik bakış açılarını olumlu yönde etkilerken, Rusya, Çin ve Doğu Avrupa ülkelerine yönelik algıları bu ülkelerden gelen ürünlere yönelik bakış açılarını da olumsuz etkilemektedir (Kaynak ve Kara, 2002: 945). Ülkelerin ürünlerine yönelik istenmeyen imajları değiştirmesi de oldukça zordur. Örneğin Çin son dönemlerde her ne kadar kalitesi yüksek ürünler üretmiş olsa da düşük kaliteli ürün ülkesi algısını uzun süre değiştirememiştir (Jaworski ve Fosher, 
2003: 101). Ancak ülkenin ürünlerine yönelik algılar ürün kategorilerine göre değişebilmektedir. Ülkenin bir ürün kategorisinde istenmeyen bir imaja sahipken başka bir ürün kategorisinde istenen bir imaja sahip olabilmekte veya bir ürün kategorisinde ön plana çıkabilmektedir. Örneğin İsviçre çakı ve saat üretiminde, Japonya elektronik eşyalarda, Belçika çikolata üretiminde, ABD uzay teknolojilerinde, İtalya moda tasarımlarında, Almanya otomotiv ve makine sanayinde, Hollanda peynir üretiminde, Fransa şarap ve parfümeride iyi bir imaja sahiptir (Kotler vd., 2000: 352).

\subsection{Tüketici Etnosentrizmi}

Etnosentrizm kelimesi Yunanca ethnos (1rk) ve kentron (merkez) kelimelerinin birleşimiyle oluşmuştur (Klopf, 2001: 102). Sosyolojik bir kavram olarak ilk defa 1906 yılında Sumner tarafından kullanılmıştır (Shimp ve Sharma, 1987: 280). Sumner etnosentrizmi "bireyin dahil olduğu grubu her şeyin merkezinde görmesi ve bu grup dişında kalan her şeyi grubunu temel alarak değerlendirmesi" şeklinde tanımlamaktadır (Sumner, 1906: 13). Shimp ve Sharma da (1987: 280) etnosentrizmi bireyin içinde bulunduğu grubu her şeyin merkezi olarak görmesi ve diğer sosyal grupları kendi grubunun bakış açısıyla değerlendirmesi, kendi kültürüne benzer özelliklere sahip kişileri onları hiç tanımadan kabullenmesi ve diğer etnik özelliklere sahip kişileri de reddetme davranışı göstermesi olarak tanımlamaktadır. Kendi grubunu dolayısıyla kendi kültürünü merkeze alan birey diğer kültürleri kendi kültürüne göre yargılamakta ve kendi kültürünü diğer kültürlerden üstün görmektedir (Uyar ve Dursun, 2015: 364). Birey yaşamı boyunca aile, iş, arkadaş gibi çok farklı gruplara girerek insanlarla etkileşimde bulunmakta ve bu grupların etkisiyle davranış ve tutumları şekillenmektedir. Bu nedenle etnosentrizmi sadece irk bağlllı̆̆1 şeklinde düşünmemek gerekir (Yue vd., 2014: 108). Etnosentrizmde kişinin aidiyet hissettiği iç grup ve bu grup dışındakilerin oluşturduğu dış grup şeklinde iki kavram bulunmaktadır (Lantz ve Loeb, 1996: 374-378). Bu gruplar doğal olarak birbirlerine muhaliftirler ve aynı gruba dahil üyeler birbirlerine yüksek derecede bağlılık gösterirken, diğer grubu reddetme davranışı sergilemektedirler (Luque-Martínez vd., 2000: 1354).

Bireylerin kendi toplumlarını ya da ülkelerini genel olarak diğer ülkeler veya toplumlardan üstün görme eğilimi olan etnosentrizm kavramı tüketici etnosentrizmi kavramını doğurmuştur (Aydoğan, 2019: 90). Tüketicilerin yabancı ürünleri satın almasının ve kullanmasının ne kadar uygun veya ahlaki olduğuna yönelik görüş ve düşünceleri ifade eden tüketici etnosentrizmi (Aksu Armağan ve Gürsoy, 2011: 67) ise tüketicilerin satın alma davranışlarını etkileyen tutumlarına, bireysel özelliklerine, niyetlerine ve tercihlerine odaklanmaktadır (Aydoğan, 2019: 89). Dolayısıyla tüketici etnosentrizmi kavramı tüketicilerin satın alma davranışlarından çok eğilimlerini ve yerli ya da yabancı ürünlere yönelik hislerini yansıtmaktadır (Sharma ve Shimp, 1987: 288). Elibol (2020: 94), tüketici etnosentrizmini bir tüketicinin yabancı ülkelerin mal ya da hizmetleri yerine kendi ülkesinde üretilen mal veya hizmetleri satın alması ve kullanması, ekonomik olarak kendi ülkesindeki işletmeleri desteklemesi olarak tanımlamaktadır. Tüketici etnosentrizminin üç bileşeni bulunmaktadır. Bunlar; bir bireyin kendi ülkesindeki ürünlerin diğer ülkelerdeki ürünlerden daha üstün olduğu algısı anlamına gelen bilişsel bileşen, tüketicilerin ülkelerine olan sevgilerini, aidiyet duygularını ve duygusal bağlılıklarını yansıtan duygusal bileşen ve bireyin yabancı ürünler yerine kendi ülkesinde üretilen ürünleri kullanması ve satın alması yönünde hissettiği zorunluluk anlamina gelen normatif bileşendir (Vida ve Reardon, 2008: 34-44).

Tüketici etnosentrizmini etkileyen birçok faktör bulunmaktadır. Bu bağlamda Shimp ve Sharma (1987: 288), ekonomik, demografik, politik ve sosyo-psikolojik faktörlerin üzerinde durmak gerektiğini belirtmektedir. Elibol (2020: 96-98) ise tüketici etnosentrizmini etkileyen faktörleri; milliyetçilik, vatanseverlik, muhafazakarlık, toplumculuk, kültürel benzerlik, düşmanlık, meşe ülke ve demografik faktörler şeklinde siralamaktadır. Aksu Armağan ve Gürsoy (2011: 68-69) da tüketicileri etnosentrik davranışlara iten başlıca faktörlerin ekonomik ve ahlaki faktörler olduğunu belirtmektedir. Tüketicilerin yabancı ürünlerin işsizlik vb. sorunlara yol açarak ülke ekonomisine zarar vereceği düşüncesi ile yerli ürünlere yönelmesi (Watson ve Wright, 2000: 1153) ekonomik kaygıyı ifade erken, yabancı ürünleri satın almanın milliyetçilik anlayışına ters bir durum olduğu ve ülkesini seven insanların yerli ürünleri tercih etmesi gerektiği düşüncesi ise ahlaki kaygıyı ifade etmektedir (Aysuna, 2006: 94). 
Tüketici etnosentrizmi yabancı işletmeler için büyük dezavantajlar içerirken, yerli işletmeler için de aynı ölçü de avantajlar içermektedir. Yabancı işletmeler sahip oldukları bu dezavantajı avantaja dönüştürmek için tüketicilerin etnosentrik eğilimlerini belirlemeyi amaçlamaktadırlar. Bu amaçla birçok çalışma yapılmıştır. Bu çalışmaların en önemlilerinden biri Cetscale ölçeğidir (Elibol, 2020: 94). Bu ölçek daha önceki ölçeklerin tüketici davranışlarını açıklama konusunda yetersiz kalması nedeniyle geliştirilmiştir (Shimp ve Sharma, 1987: 281). Tüketici etnosentrizmini ölçen tek ölçek olma özelliğine sahip olan Cetscale Ölçeği, farklı çalışmalarda yeniden yapılandırılarak güncellenmiştir. 17 ifadeden oluşan ölçeğin daha sonra 10 ifadelik ve 6 ifadelik versiyonları oluşturulmuş ve kullanılmıştır (Özdemir vd., 2018: 358). Dolayısıyla ölçek oluşturulduğu tarihten itibaren pek çok defa test edilmiş ve geçerliliği kabul edilmiştir (Değermen vd., 2017: 105).

Etnosentrizmin işletmeler açısından olumlu veya olumsuz birçok sonucu bulunmaktadır. Tüketici etnosentrizmi sadece tüketicilerin kendilerinden olanı üstün görme güdüsüyle değil, aynı zamanda kendilerinden olana zarar verme düşüncesiyle de tüketici tercihlerini etkilemektedir (Reardon vd., 2005: 744). Etnosentrik tüketiciler yerli ürünleri desteklemekte, yabancı ürünleri ise sorgulamakta ve bu ürünlere karşı ön yargılı olmaktadır (Kwak ve ark., 2006: 371). Etnosentrik eğilimi olmayan tüketiciler ürünleri kalite, fiyat ve performans gibi kriterlere göre değerlendirirken (Bawa, 2004: 44), etnosentrik tüketiciler uluslararası ticaretin azaltılması ve ithal ürünlere daha yüksek vergiler koyulması gerektiğini düşünmektedir. Etnosentrizm tüketici tutumlarını da etkilemektedir (Supphellen ve Grønhaug, 2003: 210). Etnosentrik eğilim, tüketicilerin ulusal markalara yönelik kalite algısını, bağlılığını ve marka kişiliğini olumlu yönde etkilerken (Yıldız ve Koçan, 2019: 322), yabanc1 ürünlere yönelik tüketici değerlendirmelerini ve satın alma niyetini olumsuz etkilemektedir (Torres ve Gutierrez, 2007: 6). Etnosentrizmin bu etkileri pahalı ürünler, moda ürünleri ve karmaşık ürünlerde daha fazla olmaktadır (Bandyopadhyay, 2014: 22). Bu farklılığın sebebi muhtemelen bu ürünlerle ilgili satın alma riskidir (Uğur ve Sarığlu Uğur, 2019: 5).

Küreselleşme nedeniyle rekabetin arttığı uluslararası pazarlarda işletmelerin yaşamlarını devam ettirmeleri oldukça zorlaşmaktadır. Bu nedenle tüketici etnosentrizmi işletmelerin uluslararası pazarlama stratejilerini belirlerken, göz önünde bulundurmaları gereken önemli bir kavramdır. Tüketici etnosentrizminin doğru bir şekilde ölçülüp analiz edilmesiyle oluşturulacak olan uluslararası pazarlama stratejileri işletmelere bu rekabet ortamında önemli avantajlar sağlayacaktır (Tuncer ve Gökşen, 2016: 68).

\section{3. Ürün Yargıları}

Bir ürünün tüketici pazarına girmesi için tüketicilerin onu kabul etmeye istekli olması gerekir (De Barros vd., 2011: 101). O ürünü kabul etmeye istekli olmaları için ise o ürüne yönelik olumlu yargılara sahip olmaları gerekmektedir. Tüketiciler ürünün fiyatı, kalitesi, ambalajı, sağladığı fayda ya da statü, paketlemesi, reklamların çekiciliği vb. konularda olumlu yargılara sahip olduklarında o ürünü satın alma olasılıkları da artacaktır. Ancak insanların bir ürüne dair yargıları fiyat, marka, paketleme, reklam vb. pazarlama unsurları dışında birçok faktörden etkilenmektedir. Menşe ülke ve menşe ülke imajı da bu faktörlerdendir (Yasin vd., 2007: 38).

Üretici ülkenin imajının, ürün kalitesine ilişkin yargılar üzerinde önemli bir etkiye sahip olduğu birçok araştırmada ispatlanmıştır (Bilkey ve Nes, 1982; Han, 1988; Hong ve Wyer, 1989; Maheswaran, 1994; Papadopoulos ve Heslop, 1993). Ürünle ilişkilendirilen ülke tüketicilerin ürün yargılarını etkilemektedir. Örneğin tüketicilerin Kore' ye ve Korelilere yönelik olumlu düşünceleri Goldstar kompakt disk oynatıcının teknolojik olarak gelişmiş ve yüksek kalitede olduğu algısının oluşmasına sebep olabilir (Klein vd., 1998: 89).

Bir ülkenin imajının ürün yargılarını etkileyeceğine yönelik birçok araştırma olmasına rağmen, literatürde farklı sonuçlara ulaşan çalışmalar da mevcuttur. Klein vd. (1998) nitelik yargılarının genel olarak satın almayı etkilediği varsayılmasına rağmen, tüketicilerin yabancı ürünlere ilişkin değerlendirmeleri üzerine yapılan araştırmaların çoğunun, satın alma niyetlerini veya kararlarını doğrudan ölçmediğini belirtmiştir. Dolayısıyla tüketicilerin ürünle ilgili yargıları olumlu olsa bile menşe ülkeye yönelik düşünceleri olumsuz olduğunda satın alma işlemini gerçekleştirmeyebileceklerdir. Örneğin, İkinci Dünya Savaşı sırasında Japonların elinde korkunç bir 
işgale ve katliama maruz kalmış bir şehir olan Nanjing'de yaşayan bir tüketiciden Sony kompakt disk oynatıcının (Japon malı) özelliklerini derecelendirmesi istenirse, ürüne yüksek puanlar vermesi muhtemeldir. Ülkesinin tarihinde gerçekleşen olaylar, Sony'nin üst düzey, yüksek kaliteli bir marka olduğu gerçeğine karşı onu kör kılmamaktadır. Ancak Sony markasını satın alıp almayacağı sorulursa, evine asla bir Japon ürünü götürmeyeceğini söyleyebilir (Klein vd., 1998: 89-90).

Dolayısıyla ürün yargısının satın alma isteği üzerindeki etkisi tüketicinin ürün hakkındaki bilgisinden de etkilenmektedir. Bir ürünü değerlendirirken, tüketici mevcut bilgilere dayanarak bir değerlendirme yapacaktır (Adaval ve Monroe, 2002). Belirli bir ürünü değerlendirecek bilgiden yoksun olan tüketiciler, değerlendirmelerini kendilerine verilen referanslara göre yapacaklardır (De Barros vd., 2011: 101). Örneğin, 2005 yılında Danimarka ve İslam ülkeleri arasında gerginliğe sebep olan bir karikatür krizi yaşanmıştır. Danimarkalı bir sanatçının İslam Peygamberi Hz. Muhammed (sav)'in karikatürlerini çizmesi Müslümanlar tarafından tepkiyle karşılanmış, birçok Müslüman ülkede protestolar yapılmıştır. Bu olaydan haberi olan Müslümanlar Danimarka menşeli tanınmış bir spor giyim markası olan Hummel'ı, ürünlerine yönelik olumlu yargıya sahip olsalar bile satın almayabilirler. Ancak bu olaylardan haberdar olmayan Müslüman bir tüketici marka ile ilgili olumlu yargılara sahip olduğu için markayı satın alabilir.

\subsection{Literatür}

Literatürde ülke imajı, tüketici etnosentrizmi, ürün yargıları ve satın alma istekliliği arasındaki ilişkileri inceleyen çalışmalar mevcuttur. Ancak ülke imajının diğer üç değişken üzerindeki etkilerini inceleyen çok fazla çalışma bulunmamaktadır. Bu çalışmada Fernandez-Ferrin vd. (2015) ile Klein vd. (2018)'nin çalışmalarında kullandığı modelden faydalanılmış ve bu modele ülke imajı da eklenerek araştırmanın modeli oluşturulmuştur. Oluşturulan model doğrultusunda literatür incelenerek daha önce yapılan çalışmalarla hipotezler desteklenmiştir.

Literatür incelendiğinde Aydın ve Biçer (2017), ABD, Çin ve Güney Kore ülkelerine yönelik Y kuşağının algılarını belirlemek amacıyla yaptıkları çalışmada yabancı ülke imajının yabancı meşeli ürün alma isteği üzerine pozitif etkisi olduğunu tespit etmiştir. Öztürk vd. (2017), Yemen, Fransa ve Almanya' da ülke imajının farklı kültürlerde satın alma niyeti üzerindeki belirleyiciliğini sınamak amacıyla gerçekleştirdikleri çalışmada duygusal ülke imajının satın alma niyetini pozitif etkilediği sonucuna ulaşmıştır.

Öztürk vd. (2019), tüketici düşmanlığının ülke imajı ve ürün değerlendirmesi üzerindeki etkilerini anlamak amacıyla gerçekleştirdikleri çalışmada genel ülke imajının insan boyutunun ürün değerlendirmesi üzerinde pozitif, aynı şekilde ürün değerlendirmesinin de satın alma isteği üzerinde pozitif bir etkiye sahip olduğunu tespit etmiştir. Dursun vd. (2019), Moskova'da yaşayan Rus tüketiciler üzerinde yaptıkları araştırmada ülke imajının ürün değerlendirmesi üzerinde, aynı şekilde ürün değerlendirmesinin de satın alma niyeti üzerinde pozitif etkisi olduğu sonucuna ulaşmışlardır. Dursun vd. (2014), Almanya'nın 4 farklı şehrinde Alman tüketiciler üzerinde yaptıkları çalışmada ülke imajının gelişmişlik seviyesi boyutunun ürün değerlendirmesi ve satın alma niyeti üzerinde, işgücü kalitesi boyutunun ise ürün değerlendirmesi üzerinde pozitif etkiye; ürün değerlendirmesinin satın alma niyeti üzerinde pozitif etkiye; tüketici etnosentrizminin ise ürün değerlendirmesi üzerinde negatif etkiye sahip olduğunu tespit etmişlerdir.

Ülker Demirel (2020), tüketicilerin zihinlerinde ülke imajı ve satın alma istekliliği ilişkisini etkileyebilecek unsurları araştırmak amacıyla gerçekleştirdikleri çalışmada ülke imajının ürün yargıları ve satın alma istekliliği üzerinde pozitif etkiye; ürün yargılarının satın alma istekliliği üzerinde pozitif etkiye sahip olduğunu ve ürün yargilarının ülke imajı ve satın alma istekliliği arasındaki ilişkide aracılık rolünün bulunduğunu tespit etmiştir. İzmir (2017), çalışmasında menşe ülke imajı ve ürün değerlendirmesinin tüketicilerin aşinalıkları olmadığı durumda satın alma niyetini olumlu etkilediği, menşe ülke imajının tüketicilerin aşinalıkları olmadığı durumda ürün değerlendirmesi aracılığıyla da satın alma niyetini olumlu etkilediği ve ürün değerlendirmesinin tüketicilerin aşinalıklarının olduğu durumda satın alma niyetini olumlu etkilediği sonucuna ulaşmıştır. Mutlu vd. (2011), Türk ve Suriyeli tüketicilerin etnosentrik eğilimlerini ve ülke imajı, ürün değerlendirmesi, düşmanlık algılaması, ürünlere yönelik tutum ve etnosentrik eğilimlerin satın alma niyeti üzerindeki etkisini belirlemek amacıyla gerçekleştirdikleri çalışmada, Tük 
tüketicilerin etnosentrik eğilimlerinin Suriye meşeli ürünleri satın alma niyetlerini negatif etkilediği; Türk tüketicilerinin Suriye' ye yönelik ülke imajı algılamalarının ve Suriye menşeli ürünlere yönelik değerlendirmelerinin Suriye menşeli ürünleri satın alma niyetleri üzerinde etkili olduğu sonuçlarına ulaşmiştır.

Fernandez-Ferrin vd. (2015), düşmanlık ve etnosentrizmin öncüllerini ve sonuçlarını tek bir model içinde araştırmak ve katılımcıların belirli bir ürün kategorisine ilişkin değerlendirmelerini belirlemek amacıyla yaptıkları çalışmada etnosentrizmin ürün yargısı ve satın alma istekliliği üzerinde negatif, ürün yargısının ise satın alma istekliliği üzerinde pozitif bir etkisi olduğu sonucuna ulaşmışlardır. Klein vd. (1998), Çinli tüketicilerin Japonya ve Japon ürünlerine yönelik tutumlarını belirlemek amacıyla gerçekleştirdiği çalışmada tüketici etnosentrizminin ürün yargıları ve satın alma istekliliğini negatif etkilediğini tespit etmiştir.

\section{Araştırmanın Metodolojisi}

\subsection{Araştırmanın Amaci}

Araştırmanın amacı ülke imajının etnosentrizm, ürün yargısı ve satın alma istekliliği üzerindeki etkisini ve etnosentrizm ve ürün yargısının ülke imajı ve satın alma istekliliği arasındaki ilişkide aracılık rolünü incelemektir. Bu amaç doğrultusunda ilgili literatür taranmış ve aşağıdaki model ve hipotezler oluşturulmuştur.

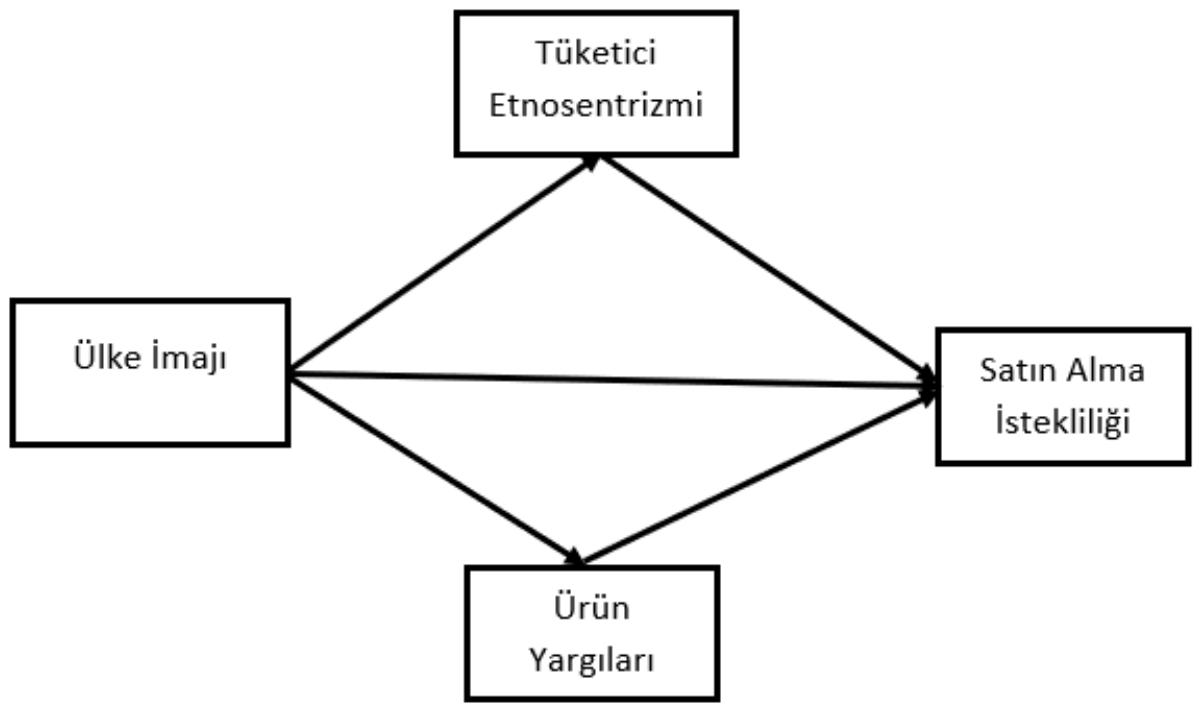

Şekil 1. Araştırmanın Modeli

H1: Ülke imajı yabancı ürün satın alma istekliliği üzerinde pozitif bir etkiye sahiptir.

H2: Ülke İmajı etnosentrizm üzerinde negatif bir etkiye sahiptir.

H3: Ülke imajı ürün yargısı üzerinde pozitif bir etkiye sahiptir.

H4: Etnosentrizm yabancı ürün satın alma istekliliği üzerinde negatif bir etkiye sahiptir.

H5: Ürün yargısı yabancı ürün satın alma istekliliği üzerinde pozitif bir etkiye sahiptir.

H6: Etnosentrizm, ülke imajı ve yabancı ürün satın alma istekliliği arasındaki ilişkide aracılık rolüne sahiptir.

H7: Ürün yargısı, ülke imajı ve yabancı ürün satın alma istekliliği arasındaki ilişkide aracılık rolüne sahiptir.

\section{2. Örnekleme Planı}

Araştırmanın evreninin Türkiye'de yaşayan ve beyaz eşya kullanıcısı olan bireyler oluşturmaktadır. Araştırmanın evreni bu örneklem içerisinden seçilen 396 katılımcıdan oluşmaktadır. Örneklemin evreni temsil etme yeterliliği araştırmalar için oldukça önemlidir. Bu nedenle örneklemin evreni temsil edecek yeterlilikte olup olmadığını belirlemek için literatürde yer alan çalışmalardan faydalanılmıştır. MacCallum vd. (2011), örneklem sayısının belirlenmesinde ankette yer alan ifadelerin 4 katını yeterli görmektedir. Gegez (2007), bir araştırma için örneklem büyüklügüunün 300-500 arasında olmasının yeterli olduğunu belirtmektedir. Ayrıca Yazıcıoğlu ve 
Erdoğan (2004), 100 milyonluk bir evren için evren büyüklüğünün 384 olmasının yeterli olduğunu savunmaktadır. Bu bilgiler dikkate alındığında araştırmada kullanılan 396 örneklem büyüklügünün analiz için yeterli olduğu söylenebilir.

\subsection{Araştırma Yöntemi}

Araştırmada tesadüfi olmayan örnekleme yöntemlerinden kolayda örnekleme yöntemi kullanılmıştır. Bunun sebebi bütün dünyayı etkisi altına alan covid 19 pandemisi nedeniyle katılımcılara ulaşmada sıkıntılar yaşanmasıdır. Bu sıkıntıları en aza indirmek ve mümkün olan en fazla katılımcıya ulaşmak amacıyla kolayda örnekleme yöntemi kullanılmıştır. Ayrıca pandemiden yüz yüze anket yapmanın mümkün olmaması nedeniyle katılımcılara online anket uygulanmısstır. Veriler toplanmadan önce Gümüşhane Üniversitesi Etik Kurul Birimine etik kurul onayı için başvuruda bulunulmuş ve 09.06.2021 tarihli ve 2021/04 sayılı etik kurul onayı alınmıştır. Etik kurul onayı alındıktan ve alanında uzman iki akademisyen tarafından ön kontrolü yapıldıktan sonra 01.07.2021-01.08.2021 tarihleri arasında anket formu 407 kişiye uygulanmıştır. Toplanan anket verilerinden 11 tanesi sağlıklı doldurulmadıkları tespit edildiği için analizden çıkarılmıştır. Dikkate alınan 396 veri SPSS 21 programinda analize tabi tutulmuştur. Hayes (2013), birden fazla aracı değişkeni olan araştırmalarda Yapısal Eşitlik Modellemesinin kullanılmasının aracı etkiyi belirlemede yetersiz kaldığını belirtmektedir. Araştırmanın etnosentrizm ve ürün yargısı olmak üzere iki aracı değişkeni olması sebebiyle aracı etkiyi belirlemek için Process programı kullanılmiştır.

\subsection{Araştırmada Kullanılan Ölçekler}

Araştırmada kullanılan ölçekleri belirlemek amacıyla literatür incelenmiş ve konuyla ilgili en fazla kullanılan ölçekler tercih edilmiştir. Araştırmada kullanılan ülke imajı ölçeği De Nisco vd. (2016)'nin çalışmasından alınmış ve 5 ifadeden oluşmaktadır. Etnosentrizm, ürün yargısı ve satın alma istekliliği ölçekleri Klein vd. (1998)'nin çalışmasından alınmıştır. Bu ölçeklerin her biri 6'şar ifadeden oluşmaktadır. Etnosentrizm ölçeği, daha önce Avc1 (2020) tarafından da kullanılmıştır. Ölçeklerin tamamı $5^{\prime}$ li likert tipine göre düzenlenmiştir.

\subsection{Analiz ve Bulgular}

\subsubsection{Katılımcıların Demografik Özellikleri}

Tablo 1. Katılımcıların Demografik Bilgileri

\begin{tabular}{|c|c|c|c|}
\hline Değişken & Düzey & $n$ & $\%$ \\
\hline \multirow{2}{*}{ Cinsiyet } & Kadın & 124 & 31 \\
\hline & Erkek & 276 & 69 \\
\hline \multirow{3}{*}{ Yaş } & $18-28$ & 169 & 43 \\
\hline & $29-39$ & 178 & 45 \\
\hline & 40 ve üzeri & 49 & 12 \\
\hline \multirow{4}{*}{ Gelir } & \multirow{2}{*}{$\begin{array}{l}3000 \text { TL ve alt1 } \\
3001-6000\end{array}$} & 147 & 37 \\
\hline & & 152 & 38 \\
\hline & $6001-9000$ & 69 & 17 \\
\hline & 9001 TL ve üzeri & 28 & 8 \\
\hline \multirow{2}{*}{ Medeni Durum } & Evli & 183 & 46 \\
\hline & Bekar & 213 & 54 \\
\hline \multirow{5}{*}{ Eğitim Düzeyi } & \multirow{2}{*}{$\begin{array}{l}\text { İlköğretim } \\
\text { Ortaöğretim }\end{array}$} & 31 & 8 \\
\hline & & 115 & 29 \\
\hline & Ön lisans & 86 & 22 \\
\hline & Lisans & 111 & 28 \\
\hline & Lisansüstü & 53 & 13 \\
\hline \multirow{8}{*}{ Meslek } & Serbest Meslek & 62 & 16 \\
\hline & Esnaf & 26 & 7 \\
\hline & Memur & 119 & 30 \\
\hline & Sözleşmeli Personel & 29 & 7 \\
\hline & İşçi & 51 & 13 \\
\hline & Ev Hanımı & 28 & 7 \\
\hline & Öğrenci & 76 & 19 \\
\hline & Emekli & 5 & 1 \\
\hline \multirow{2}{*}{ Yabancı bir beyaz eşya markası kullanıyor musunuz? } & Evet & 343 & 87 \\
\hline & Hayır & 53 & 13 \\
\hline & Anne & 108 & 27 \\
\hline
\end{tabular}




\begin{tabular}{|c|c|c|c|}
\hline \multirow{3}{*}{$\begin{array}{l}\text { Beyaz eşya alırken hangi marka olacağına aile içerisinde kim karar } \\
\text { veriyor? }\end{array}$} & Baba & 61 & 15 \\
\hline & Çocuklar & 7 & 2 \\
\hline & Ailece Ortak Karar & 220 & 56 \\
\hline \multirow{2}{*}{ Alman malı bir beyaz eşya markası kullanıyor musunuz? } & Evet & 271 & 68 \\
\hline & Hayır & 125 & 32 \\
\hline \multirow{2}{*}{$\begin{array}{l}\text { Beyaz eşya ürünlerinin satın alımında belirli bir markayı mı tercih } \\
\text { edersiniz? }\end{array}$} & Evet & 294 & 74 \\
\hline & Hayır & 102 & 26 \\
\hline \multirow{3}{*}{ Beyaz eşyalar hakkında ne kadar bilgi sahibisiniz? } & Çok az bilgi sahibiyim & 113 & 28 \\
\hline & Yeterli miktarda bilgi sahibiyim & 245 & 62 \\
\hline & Detaylı bilgi sahibiyim & 38 & 10 \\
\hline \multicolumn{2}{|l|}{ Toplam } & 396 & 100,0 \\
\hline
\end{tabular}

Tablo 1'deki veriler incelendiğinde katılımcıların çoğunun erkek (\%69) ve bekar (\%54) olduğu, çoğunluğunun da 18-39 yaş arasında (\%86) olduğu görülmektedir. Ayrıca katılımcıların önemli bir bölümü 6000 TL ve altında gelire sahiptir. Ortaöğretim (\%29), ön lisans (\%22) ve lisans (\%28) mezunlarının oranları birbirine yakındır ve katılımcıların çoğunluğu memur olarak görev yapmaktadır. Katılımcıların büyük çoğunluğu yabancı bir beyaz eşya markası (\%87) kullandığını belirtirken, bunların önemli bir kısmı da Alman malı bir beyaz eşya markası (\%68) kullanmaktadır. Ayrıca çoğu katılımcı beyaz eşya satın alınırken hangi marka olacağına ailece ortak karar (\%56) verdiklerini belirtmiştir. Katılımcıların önemli bir kısmı beyaz eşya satın alırken belirli bir markayı tercih ettiklerini (\%74) belirtirken, önemli bir kısmı da beyaz eşyalar hakkında yeterli miktarda bilgiye sahip olduğunu (\%62) belirtmektedir.

\subsubsection{Faktör Analizi}

Araştırmada kullanılan ölçeklerin faktör yapısını ve faktör analizi yapılıp yapılamayacağını belirlemek amacıyla açıklayıcı faktör analizi yapmadan önce KMO (Kaiser Meyer-Olkin) ve Bartlett Küresellik testleri yapılmıştır. Örneklemin yeterli olabilmesi için KMO değerinin 0,60' da fazla (Gürbüz ve Şahin, 2017: 325), faktör analizi yapılabilmesi için ise Bartlett Küresellik test değerinin 0,05'ten küçük olması gerekmektedir (Tabachnick ve Fidell, 1996: 674). Analizler sonucunda elde edilen değerler tablo 2 'de gösterilmektedir.

Tablo 2. KMO ve Bartlett's Test Sonucları

\begin{tabular}{|l|l|l|l|l|}
\hline Ölçekler & KMO Testi & Bartlett's Testi & $d f$ & $p$ \\
\hline Ülke İmaji &, 748 & 1006,315 & 10 &, 000 \\
\hline Etnosentrizm &, 866 & 1095,266 & 15 &, 000 \\
\hline Ürün Yargisı &, 876 & 1284,531 & 15 &, 000 \\
\hline Satın Alma İstekliliği &, 900 & 1260,627 & 15 &, 000 \\
\hline
\end{tabular}

Tablo 2'de yer alan değerler incelendiğinde örneklemin yeterli olduğu ve araştırma verilerinin faktör analizine uygun olduğu görülmektedir. Dolayısıyla KMO ve Bartlett Küresellik değeri belirlendikten sonra açıklayıcı faktör analizi yapılmıştır. Faktör analizi sonucunda elde edilen değerler tablo 3 'te gösterilmektedir.

Tablo 3. Açıklayıcı Faktör Analizi Sonuçları

\begin{tabular}{|c|c|c|c|c|}
\hline İfadeler & Boyutlar & Faktör Yükü & Varyans Yüzdesi & Öz Değer \\
\hline UI1 & \multirow{5}{*}{ Ülke İmaj1 } & 675 & \multirow{5}{*}{62,213} & \multirow{5}{*}{3,111} \\
\hline UI2 & & 767 & & \\
\hline UI3 & & 855 & & \\
\hline UI4 & & 856 & & \\
\hline UI5 & & 777 & & \\
\hline E1 & \multirow{6}{*}{ Etnosentrizm } & 709 & \multirow{6}{*}{60,907} & \multirow{6}{*}{3,654} \\
\hline E2 & & 797 & & \\
\hline E3 & & 858 & & \\
\hline E4 & & ,772 & & \\
\hline E5 & & 697 & & \\
\hline E6 & & 835 & & \\
\hline UY1 & \multirow{6}{*}{ Ürün Yargis1 } & 853 & \multirow{6}{*}{63,641} & \multirow{6}{*}{3,818} \\
\hline UY2 & & 642 & & \\
\hline UY3 & & 863 & & \\
\hline UY4 & & 673 & & \\
\hline UY5 & & ,904 & & \\
\hline UY6 & & 814 & & \\
\hline S1 & & 853 & & \\
\hline
\end{tabular}




\begin{tabular}{|c|c|c|c|c|}
\hline S2 & \multirow{5}{*}{$\begin{array}{l}\text { Satın Alma } \\
\text { İstekliliği }\end{array}$} & 855 & \multirow{5}{*}{64,975} & \multirow{5}{*}{3,898} \\
\hline S3 & & 872 & & \\
\hline S4 & & 685 & & \\
\hline S5 & & 814 & & \\
\hline S6 & & ,729 & & \\
\hline
\end{tabular}

Açıklayıcı faktör analizi sonuçları incelendiğinde araştırmada kullanılan ölçeklere ait ifadelerin tamamının faktör yüklerinin 0,40'tan yüksek olduğu tespit edilmiştir. Dolayısıyla faktör analizi sonucunda ülke imajı ölçeği orijinalinde olduğu gibi 5 ifadeden, etnosentrizm ölçeği 6 ifadeden, ürün yargısı ölçeği 6 ifadeden ve satın alma istekliliği ölçeği 6 ifadeden oluşmuştur.

\subsubsection{Güvenilirlik Test Sonuçları}

Açıklayıcı faktör analizinden sonra araştırmada kullanılan ölçeklerin güvenilirliklerini belirlemek amacıyla Cronbach Alpha testi yapılmıştır. Bu test sonucunda elde edilen değerlerin 0,70'ten büyük olması ölçeklerin güvenilir olduğu, 0,40'tan küçük olması ise ölçeklerin güvenilir olmadığı anlamına gelmektedir. Analiz sonucunda elde edilen değerler tablo 4'te gösterilmektedir.

Tablo 4. Güvenilirlik Testi Sonuçları

\begin{tabular}{|l|l|l|}
\hline Ölçekler & Madde Sayısı & Cronbach Alpha \\
\hline Ülke İmajı & 5 &, 846 \\
\hline Etnosentrizm & 6 &, 870 \\
\hline Ürün Yargısı & 6 &, 881 \\
\hline Satın Alma İstekliliği & 6 &, 890 \\
\hline
\end{tabular}

Tablo 4 incelendiğinde tüm ölçeklerin Cronbach Alpha katsayılarının 0,70'ten büyük olduğu görülmektedir. Bu durum tüm ölçeklerin güvenilir olduğu anlamına gelmektedir.

\subsubsection{Korelasyon Analizi}

Araştırmada kullanılan değişkenlerin birbiriyle ilişkilerini ve bu ilişkilerin yönünü belirlemek amacıyla korelasyon analizi yapılmıştır. Korelasyon analizine ilişkin sonuçlar tablo 5'de gösterilmektedir.

Tablo 5. Korelasyon Analizi Sonuçları

\begin{tabular}{|l|l|l|l|l|}
\hline & Ülke İmajı & Etnosentrizm & Ürün Yargısı & Satın Alma İstekliliği \\
\hline Ülke İmajı & 1 & & & \\
\hline Etnosentrizm &,- 252 & 1 & & \\
\hline Ürün Yargısı &, 570 &,- 334 & 1 & \\
\hline Satın Alma İstekliliği &, 469 &,- 605 &, 648 & 1 \\
\hline
\end{tabular}

Korelasyon analizi sonuçları incelendiğinde ülke imajı ile etnosentrizm arasında negatif yönlü $(\mathrm{r}=-0,252, \mathrm{p}<0,01)$, ülke imajı ve ve ürün yargısı arasında pozitif yönlü $(\mathrm{r}=0,570, \mathrm{p}<0,01)$, ülke imaj1 ve satın alma istekliliği arasında pozitif yönlü $(\mathrm{r}=0,469, \mathrm{p}<0,01)$, etnosentrizm ile ürün yargısı arasında negatif yönlü $(\mathrm{r}=-0,334, \mathrm{p}<0,01)$, etnosentrizm ve satın alma istekliliği arasında negatif yönlü $(\mathrm{r}=-0,605, \mathrm{p}<0,01)$ ve ürün yargısı ile satın alma istekliliği arasında pozitif yönlü $(\mathrm{r}=-0,312$, $\mathrm{p}<0,01)$ anlamlı ilişkiler olduğu görülmektedir.

\subsubsection{Aracılık Etkisi}

Sosyal bilimlerde yapılan araştırmalarda genellikle tek bir aracının kullanıldığı basit aracılık modelleri tercih edilmektedir. Araştırmada birden fazla aracı varsa paralel çoklu aracılık modelleri kullanılmaktadır. Birden fazla aracı değişken olduğunda aracılık etkisi basit aracılık modelleri ile ayrı ayrı araştırıldığı takdirde her modelde aracı değişkenin değişmesi gerekmekte ve bu durum bağımlı değişkenin bağımsız değişken üzerindeki etkisinde farklılıklara sebep olmaktadır. Dolayısıyla söz konusu durum istatistiksel hatalara neden olmaktadır. Bu nedenle Hayes (2013) tarafından iki ve daha fazla aracı değişkenin yer aldığı modellerde paralel çoklu aracılık modellerinin kullanılması önerilmektedir. Bu araştırmada da Hayes (2013) tarafından önerilen çoklu aracılık modeli kullanılmıştır.

Baron ve Kenny (1986), bir modelde aracılık etkisinden söz edebilmek için üç koşulun sağlanması gerektiğini belirtmektedir. İlk olarak bağımsız değişkenin bağımlı değişken üzerinde anlamlı bir etkisinin olması gerekmektedir. İkinci olarak bağımsız değişkenin aracı değişken üzerinde anlamlı bir etkisi olması gerekmektedir. Son aşamada bağımsız değişken ve aracı değişken birlikte analize sokulduklarında bağımsız değişkenin bağımlı değişken üzerindeki anlamlı etkisi azalmalı veya 
tamamen ortadan kalkmalıdır. Ayrıca bu aşamada aracı değişkenin de bağımlı değişken üzerinde var olan anlamlı etkisinin devam etmesi gerekmektedir. Bağımsız değişkenin bağımlı değişken üzerindeki anlamlı etkisinin tamamen ortadan kalkması durumunda tam aracılık etkisinden, bu etkinin azalması durumunda ise kısmi aracılık etkisinden söz edilebilmektedir. Bağımsız değişkenin aracı değişkenler ve bağımlı değişkenler üzerindeki etkisini gösteren değerler tablo 6 'da gösterilmektedir.

Tablo 6. Doğrudan Etki Sonuçları

\begin{tabular}{|c|c|c|c|c|c|c|}
\hline Yordanan & Yordayan & $B$ & $\beta$ (Standart B) &.$t$ & S.H. & $p$ \\
\hline Etnosentrizm & \multirow{3}{*}{ Ülke İmajı } &,- 39 &,- 25 & $-5,1204$ & 0,08 &, $000^{*}$ \\
\hline Ürün Yargısı & & ,59 & ,57 & 9,2788 & 0,04 &, $000^{*}$ \\
\hline Satın Alma İstekliliği & & ,58 & 47 & 7,5057 & 0,06 &, $000^{*}$ \\
\hline
\end{tabular}

Baron ve Kenny'nin (1986) adımları takip edilerek öncelikle ülke imajının aracı değişkenler etnosentrizm ve ürün yargısı ile bağımlı değişken satın alma istekliliği üzerindeki etkisi incelenmiştir. Analizler sonucunda ülke imajının etnosentrizm üzerinde negatif, ürün yargisı ve satın alma istekliliği üzerinde ise pozitif bir etkisi olduğu tespit edilmiştir. Bu aşama tamamlandıktan sonra bağımsız değişken ülke imajı ve aracı değişkenler etnosentrizm ve ürün yargısı ile birlikte analize sokularak bağımlı değişken satın alma istekliliği üzerindeki etkileri incelenmiştir. Analiz sonucunda ulaşılan sonuçlar tablo 7'de gösterilmektedir.

Tablo 7. Dolaylı Etki Sonuçları

\begin{tabular}{|l|l|l|l|l|l|l|}
\hline Yordanan & Yordayan & $\boldsymbol{B}$ & $\boldsymbol{\beta}$ (Standart B) & $\boldsymbol{t}$ & $\boldsymbol{t}$ S.H. & $\boldsymbol{p}$ \\
\hline \multirow{3}{*}{ Satın Alma İstekliliğii } & Ülke İmaj1 &, 14 &, 11 & 2,7715 & 0,05 &, $000^{*}$ \\
\cline { 2 - 7 } & Etnosentrizm &,- 34 &,- 43 & $-12,5004$ & 0,03 &, $000^{*}$ \\
\cline { 2 - 7 } & Ürün Yargisı &, 53 &, 44 & 10,9246 & 0,05 &, $000^{*}$ \\
\hline
\end{tabular}

Analiz sonuçları incelendiğinde aracı değişkenler etnosentrizm ve ürün yargısının bağımlı değiş̧ken satın alma istekliliği üzerindeki etkisinin devam ettiği, ülke imajının etkisinin ise azaldığ $(0,14)$ tespit edilmiştir. Bu sonuçlar Baron ve Kenny (1986)'nin belirttiği aracılık koşullarının sağlandığını göstermektedir. SPSS programındaki PROCESS makrosunda bulunan model 4 kullanılarak yapılan aracılık analizine ilişkin anlamlılık değerleri tablo 8' de gösterilmektedir.

Tablo 8. Aracı Değişkenler Anlamlılık Tablosu

\begin{tabular}{|l|l|l|l|l|}
\hline Yordanan & $\boldsymbol{F}$ & $\boldsymbol{d f 1}$ & $\boldsymbol{d f} \mathbf{2}$ & $\boldsymbol{p}$ \\
\hline Aracı 1: Etnosentrizm & 14,3686 & 1,0000 & 385,0000 &, 000 \\
\hline Aracı 2: Ürün Yargisı & 5,6501 & 1,0000 & 385,0000 &, 020 \\
\hline
\end{tabular}

Preacher ve Hayes (2008), Bootstrap işleminin çoğu koşulda belirli dolaylı etkiler için güven sinırları elde etmenin en makul ve güçlü yöntemi olduğunu ve mümkün olduğunca bootstrap güven aralığı değerlerinin kullanılması gerektiğini belirtmektedir. Bundan dolayı aracılık etkisini doğrulamak için bootstrap güven aralığı değerleri kullanılmıştır. Bootstrap güven aralığ1 değerleri, hipotezlerin kabul/ret durumları ve aracılık analizi sonuçları tablo 9'da gösterilmektedir.

Tablo 9. Hipotez ve Aracılık Testi Sonuçları

\begin{tabular}{|c|c|c|c|c|c|c|c|}
\hline Hipotezler & $\begin{array}{l}\text { Doğrudan } \\
\text { Etki }\end{array}$ & $\begin{array}{l}\text { Dolaylı } \\
\text { Etki }\end{array}$ & Aracı Etki & $\begin{array}{l}\text { Bootstrap } \\
\text { Lower Bounds }\end{array}$ & $\begin{array}{l}\text { Bootstrap } \\
\text { Upper Bounds }\end{array}$ & P Değeri & Durum \\
\hline Üİ $\rightarrow$ SAI & 0,58 & & & & & * & Kabul \\
\hline Üİं $\rightarrow$ ETNO & $-0,39$ & & & & & * & Kabul \\
\hline Üİ $\rightarrow \ddot{U} Y$ & 0,59 & & & & & * & Kabul \\
\hline ETNO $\rightarrow$ SAI & $-0,34$ & & & & & * & Kabul \\
\hline ÜY $\rightarrow$ SAİ & 0,53 & & & & & * & Kabul \\
\hline Üİ $\rightarrow \mathrm{ETNO} \rightarrow \mathrm{SA}$ & \multirow{2}{*}{0,14} & 0,13 & Kısmi & 0,0680 & 0,2064 & * & Kabul \\
\hline$\ddot{U} \dot{U} \dot{I} \rightarrow \ddot{U Y} \rightarrow S A \dot{I}$ & & 0,31 & Kismi & 0,2210 & 0,4115 & ** & Kabul \\
\hline
\end{tabular}

${ }^{*} \mathrm{p}<0,01,{ }^{* *} \mathrm{p}<0,05$

Yapılan analizler alt ve üst sınır güven aralığının sıfırı kapsamadığını göstermektedir. Bu durum etnosentrizm ve ürün yargısının ülke imajı ve satın alma istekliliği arasındaki ilişkide aracılık rolünün bulunduğunu göstermektedir. Hipotez testi sonuçları incelendiğinde, $\mathrm{p}<0,01$ anlamlılık 
düzeyinde H1 hipotezine göre ülke imajının satın alma istekliliği üzerinde 0,58 oranında pozitif yönde anlamlı etkiye, $\mathrm{H} 2$ hipotezine göre ülke imajının etnosentrizm üzerinde -0,39 oranında negatif yönde anlamlı etkiye, $\mathrm{H} 3$ hipotezine göre ülke imajının ürün yargısı üzerinde 0,59 oranında pozitif yönde anlamlı etkiye, H4 hipotezine göre etnosentrizmin satın alma istekliliği üzerinde $-0,34$ oranında negatif yönde anlamlı etkiye, H5 hipotezine göre ürün yargısının satın alma istekliliği üzerinde 0,53 oranında pozitif yönde anlamlı etkiye sahip olduğu sonucuna ulaşılmıştır. Aracı etki ile ilgili sonuçlar incelendiğinde ise, ülke imajının satın alma istekliliği üzerindeki etkisinde etnosentrizm ve ürün yargısı değişkenlerinin aracı etkiye sahip olduğu sonucuna ulaşılmıştır. Ülke imajının satın alma istekliliği üzerinde etnosentrizm aracılığ ürün yargısı aracılığı ile oluşan dolaylı etki 0,31 oranında gerçekleşmiştir. Bu sonuç ile etnosentrizm ve ürün yargısının etnosentrizm ve satın alma istekliliği arasındaki ilişkide kısmi aracılık etkisi olduğu $(0,14)$ ve bu etkide ürün yargısının daha fazla role sahip olduğu belirlenmiştir. Ayrıca aracılık etkisini doğrulamak için Bootstrap güven aralığı değerlerine de bakılması gerekmektedir. Bu değerin üst ve alt sınırı sıfırı kapsamamalıdır (Reutter ve Bigatti, 2014: 15). Bootstrap güven aralığı değerleri incelendiğinde her iki aracı değişken içinde bu değerlerin 0 'dan büyük olduğu görülmektedir. Bu sonuçlar H6 ve H7 hipotezlerini desteklemektedir

\section{Sonuç ve Değerlendirme}

Bir markanın ürünlerini uluslararası pazarlarda satabilmesi kalite, fiyat, verimlilik vb. doğrudan markayla alakalı faktörlerden etkilenebildiği gibi markanın menşe ülkesine yönelik söz konusu pazarlardaki algıdan da etkilenebilmektedir. Faaliyet gösterilen ülke pazarlarındaki tüketicilerde menşe ülkenin imajı olumluysa markanın o ülkede ürünlerini satması daha kolay olabilmektedir. Aynı şekilde tüketicilerin satın alma isteği ürünlere yönelik yargıları ve etnosentrik eğilimlerinden de etkilenebilmektedir. Bazı ülkelerde (özellikle gelişmekte olan ülkeler) Tüketicilerin etnosentrik eğilimleri ve ürünlere yönelik yargıları da menşe ülkenin imajından etkilenmektedir. Örneğin İsrail'in Müslüman ülkelerdeki imajı ve Çin'in Türki devletlerdeki imaj1 bu ülkelerin markalarının söz konusu ülkelerde zaman zaman boykot edilmesine ve çeşitli problemler yaşamasına sebep olabilmektedir. Bu çalışma ülke imajının tüketici etnosentrizmi ve ürün yargısıyla birlikte tüketicilerin yabancı ürün satın alma istekliliği üzerindeki etkisini incelemeyi amaçlamaktadır.

Çalışmada öncelikle araştırmaya katılanların demografik özellikleri belirlenmiştir. Araştırmaya katılanların \%61'i erkek, \%39'u ise kadındır. \%43'ü 18-28 yaş arası, \%45'i 29-39 yaş arası ve \%12'si 40 yaş ve üzeri katılımcılardır. \%37'si 3000 TL ve altında, \%38'i 3001-6000 TL arası, \%17'si 6001-9000 TL arası ve \% 8'i 9001 TL ve üzeri aylık gelire sahiptir. \%46'sı evli, \%54'ü ise bekardır. Katılımcıların \% 8'i ilköğretim, \%29'u ortaöğretim, \%22'si ön lisans, \%28'i lisans ve \%13'ü lisansüstü mezunudur. Araştırmaya katılanların \%16'sı serbest meslek, \%7'si esnaf, \%30'u memur, \%7'si sözleşmeli personel, \%13'ü işçi, \%7'si ev hanımı, \%19'u öğrenci ve \%1'i emeklilerden oluşmaktadır.

Katılımcıların demografik özellikleri belirlendikten sonra beyaz eşya kullanımı ve satın alımı ile ilgil sorulara verdikleri cevaplar analiz edilmiştir. Katılımcıların \%87'si yabancı bir beyaz eşya markası kullandığını belirtirken, \%56'sı beyaz eşya satın alırken hangi marka olacağına ailece ortak karar verdiklerini ifade etmektedir. Katılımcıların \%68'i Alman malı bir beyaz eşya markası kullanırken, \%74'i beyaz eşya satın alırken belli bir markayı tercih ettiklerini belirtmektedir. Katılımcıların \%28'i beyaz eşyalar hakkında çok az bilgi sahibi olduğunu, \%62'si yeterli miktarda bilgi sahibi olduğunu, \%10'u ise detaylı bilgi sahibi olduğunu belirtmektedir.

Katılımcılara ait demografik bilgiler ve beyaz eşya satın alımı ve kullanımına yönelik sorulara verdikleri cevaplar analiz edildikten sonra yapısal eşitlik analizi ile değişkenler arasındaki ilişkiler incelenmiştir. Yapılan analiz sonucunda Ülke imajı ve satın alma istekliliği arasında pozitif bir ilişki tespit edilmiştir. Bu sonuç $\mathrm{H} 1$ hipotezini desteklemektedir. Literatürde bu sonucu destekleyen çalışmalar mevcuttur. Aydın ve Biçer (2017), Öztürk vd. (2017) yaptıkları çalışmada ülke imajının yabancı ürün satın alma istekliliği üzerinde pozitif etkisi olduğunu tespit etmişlerdir.

Ulaşılan bir diğer sonuç ülke imajının tüketici etnosentrizmi üzerinde negatif etkisi olduğu sonucudur. Bu sonuçla $\mathrm{H} 2$ hipotezi desteklenmektedir. Literatürde tüketici etnosentrizmi ve ülke 
imajı arasındaki ilişkileri inceleyen çalışmalar mevcuttur. Bu çalışmalarda da ülke imajı ve tüketici etnosentrizmi arasında negatif yönlü bir ilişki olduğu tespit edilmiştir. Xin ve Seo (2020), gerçekleştirdikleri çalışmada ülke imajı ve tüketici etnosentrizmi arasında negatif bir ilişki olduğu sonucuna ulaşmışlardır. Analiz sonucunda ülke imajının ürün yargıları üzerinde pozitif bir etkisi olduğu sonucuna da ulaşılmıştır. Bu sonuç H3 hipotezini desteklemektedir. Literatürde bu sonucu destekleyen çalışmalar mevcuttur. Ülker Demirel (2020), çalışmasında ülke imajının ürün yargıları üzerinde pozitif bir etkiye sahip olduğu sonucuna ulaşmıştır.

Analizler sonucunda tüketici etnosentrizminin yabancı ürün satın alma istekliliği üzerinde negatif bir etkisi olduğu sonucuna ulaşılmıştır. Bu sonuca göre tüketicilerin etnosentrik eğilimleri arttıkça yabancı ürün satın alma istekliliği azalacaktır. Elde edilen sonuç H4 hipotezini desteklemektedir. Literatürde benzer sonuçlara ulaşan çalışmalar mevcuttur. Klein vd. (1998), çalışmasında tüketici etnosentrizminin yabancı ürün satın alma istekliliği üzerinde negatif bir etkiye sahip olduğunu tespit etmiştir. Araştırmada ulaşılan bir diğer sonuç ürün yargılarının yabancı ürün satın alma istekliliği üzerinde pozitif etkisi olduğu yönündedir. Bu sonuca göre tüketicilerin yabancı ürünlere yönelik yargıları olumlu düzeyde arttıkça yabancı ürün satın alma istekliliği de artacaktır. Bu sonuçla H5 hipotezi desteklenmektedir. Literatürde ürün yargısı ve yabancı ürün satın alma istekliliği ile ilgili benzer sonuçlar bulunmaktadır. Fernandez-Ferrin vd. (2015), çalışmalarında tüketicilerin yabancı ürünlere yönelik yargılarının yabancı ürün satın alma istekliliğini pozitif olarak etkilediği sonucuna ulaşmışlardır.

Yapılan analizler sonucunda ulaşılan bir diğer sonuç tüketici etnosentrizminin ve yabancı ürünlere yönelik ürün yargılarının ülke imajı ve yabancı ürün satın alma istekliliği arasındaki ilişkide kısmi aracılık rolünün bulunduğudur. Bu sonuç ülke imajının yabancı ürün satın alma istekliliği üzerinde etkisinin bir kısmının tüketici etnosentrimi ve ürün yargıları aracılığıla gerçekleştiği anlamına gelmektedir. Bu sonuç H6 ve H7 hipotezlerini desteklemektedir. Ülker Demirel (2020), çalışmasında ürün yargılarının ülke imajı ve yabancı ürün satın alma istekliliği arasındaki ilişkide aracılık rolünün bulunduğunu tespit etmiştir.

Araştırma sonuçlarından hareketle ülke imajının etnosentrizm ve ürün yargıları üzerinde etkili olarak tüketicilerin yabancı ürün satın alma istekliliğini etkilediği, bu nedenle uluslararası pazarlarda faaliyet gösteren işletmelerin faaliyet gösterdikleri ülkede tüketicilerde o ülkeden oldukları, o ülkeye hizmet ettikleri, kültürlerini bildikleri ve saygılı oldukları gibi algıları yerleştirmeleri, satışlarını artırmaları veya etnosentrik tutumlardan etkilenmemeleri açısından etkili olacaktır. Coca Cola'nın Ramazan aylarında yaptığı kültürel ve dini temalı reklamlar ve Tropicana markasının bu toprakların meyvelerinden üretildiği vurgusu bu duruma örnek olarak verilebilir. Bu iki marka dünyanın önde gelen içecek markaları olmalarına rağmen Türkiye pazarında yerel ve kültürel vurgular yapma gereği duymaktadır.

Daha önce gerçekleştirilen çalışmaların çoğunda olduğu gibi bu çalışmada da tüketici etnosentrizmi ile ülke imajı, ürün yargıları ve satın alma istekliliği arasında negatif bir ilişki olduğu sonucuna ulaşılmıştır. Ancak bazı çalışmalarda tüketici etnosentrizminin bu değişkenlerle arasında pozitif bir ilişki olduğu veya anlamlı bir ilişki olmadığı sonuçlarına ulaşılmıştır. Bu sonuçlara dayanarak etnosentrik eğilimlerin ülkelerin gelişmişlik seviyesi, kültürü, kuşaklar arası alg1 ve tutum farklılıkları, gelir düzeyi vb. pek çok faktörden etkilendiği öngörülebilir ve gelecekteki çalışmalar örneklemlerini bu faktörler doğrultusunda oluşturarak bu sonuçları daha iyi açıklayabilirler. Ayrıca tüketiciler genel olarak etnosentrik eğilimlere sahip olabilirken, bazı ürün gruplarında (daha çok özellikli ürünler) olmayabilirler. Bu nedenle gelecekte yapılacak çalışmaların özellikli mallarla ilgili bir araştırma yapması literatüre katkı sağlayacaktır.

\section{Kaynakça}

Adaval, R., ve Monroe, K. B. (2002). Automatic Construction and Use of Contextual Information for Product and Price Evaluations. Journal of Consumer Research, 28(4), 572-588.

Aksu Armağan, E. ve Gürsoy, Ö. (2011). Satın Alma Kararlarında Tüketici Etnosentrizmi ve Menşe Ülke Etkisinin Cetscale Ölçeği ile Değerlendirilmesi. Organizasyon ve Yönetim Bilimleri Dergisi, 3(2), 67-77. 
Ateşoğlu, İ. ve Türker, A. (2013). Türkiye'yi Ziyaret Eden Turistlerin Algıladıkları Ülke İmajı ve Olumsuz Algılara İlişkin Çözüm Önerileri. Yeni Fikir, 10, 112-135.

Aydın, H. ve Biçer, D. F. (2017). Ülke İmajının Yabancı Menşeli Ürün İnancı ve Satın Alma İsteği Üzerindeki Etkisi ve Farklı Ülke İmaj Algılarının Karşılaştırılması. Yönetim ve Ekonomi Araştırmaları Dergisi, 15(3), 149-169.

Aydoğan, S. (2019). Tüketici Etnosentrizmi ve Ülke Menşei Etkisinin Yabancı Markalı Ürün Satın Alma Niyeti Üzerine Etkisi. Beykoz Akademi Dergisi, 7(1), 89-122.

Aysuna, C. (2006). Tüketici Etnosentrizmi Etkisini Ölçmede Cetscale Ölçeği ve Türkiye Uygulaması, Yüksek Lisans Tezi, Marmara Üniversitesi Sosyal Bilimler Enstitüsü, İstanbul.

Avc1, İ. (2020). Yerli Markalı Otomobil Satın Alma Niyetinde Etnosentrizm, Ülke İmajı ve Yenilikçiliğin Etkisi: Türkiye'nin Otomobili (TOGG) Bağlamında Bir Araştırma. Bingöl Üniversitesi Sosyal Bilimler Enstitüsü Dergisi, 20, 439-466.

Bandyopadhyay, S. (2014). “Country-of-Origin Perceptions, Consumer Ethnocentrism, and Product Evaluations in the Indian Market", International Journal of Business and Social Science, 5(9), 2163.

Bannister, J. P. ve Saunders (1978). “Gauging Foreign Product Promotion”, Journal of Advertising Research, 12(February), 29-34.

Baron, R. M. ve Kenny, D. A. (1986). “The Moderator-Mediator Variable Distinction in Social Psychological Research: Conceptual, Strategic, and Statistical Considerations". Journal of Personality and Social Psychology, 51(6), 1173-1183.

Bawa, A. (2004). Consumer Ethnocentrism: CETSCALE Validation and Measurement of Extent. Vikalpa, 29(3), 43-58.

Bilkey, W. J. ve Nes, E. (1982), "Country-of-Origin Effects on Product Evaluations," Journal of International Business Studies, 13 (Spring/Summer), 89-99.

Cengiz, E. (2009). Tüketicilerin Ürün Tercihinde Rol Oynayan Ürün Menşeinin, Marka, Fiyat ve Kalite Değişkenleri Açısından İncelenmesi. Atatürk Üniversitesi İktisadi ve İdari Bilimler Dergisi, 23(2), 155-171.

De Barros, A. C., Duarte, C. ve Cruz, J. B. (2011). The Influence of Context on Product JudgementPresenting Assistive Products as Consumer Goods. International Journal of Design, 5(3), 99-112.

De Nisco, A., Mainolfi, G., Marino, V. ve Napolitano, M. R. (2016). Effect of Economic Animosity on Consumer Ethnocentrism and Product-Country Images. A Binational Study on The Perception of Germany During The Euro Crisis. European Management Journal, 34(1), 59-68.

Değermen, A., Doğan, E. ve Noyan, A. (2017). Tüketicilerin Yabancı Cep Telefonu Markalarını Yeniden Satın Alma Niyetleri Üzerinde Etnosentrizm ve Kurumsal İmajın Etkisi. Kocaeli Üniversitesi Sosyal Bilimler Dergisi, 34, 101-124.

Dursun, İ., Tümer Kabadayı, E. ve Ceylan, K. E. (2014). Alman Tüketicilerin Türk Malı Satın Alma Niyetleri: Ülke İmajı ve Tüketici Etnosentrizminin Etkileri Üzerine Bir Araştırma. Yönetim ve Ekonomi Araştırmaları Dergisi, 22, 328-347.

Dursun, I., Tumer Kabaday1, E., Ceylan, K. E. ve Koksal, C. G. (2019). Russian Consumers' Responses to Turkish Products: Exploring the Roles of Country Image, Consumer Ethnocentrism, and Animosity. Business and Economics Research Journal, 10(2), 499-515.

Elibol, A. (2020). Tüketici Satın Alma Kararlarında Tüketici Etnosentrizmi ve Sosyo-Psikolojik Faktörlerin Etkisi. Mehmet Akif Ersoy Üniversitesi Bucak İşletme Fakültesi Dergisi, 3(1), 92-130.

Fernandez-Ferrin, P., Bande-Vilela, B., Klein, J. G. ve Del Rio-Araujo, M. L. (2015). Consumer Ethnocentrism and Consumer Animosity: Antecedents and Consequences. International Journal of Emerging Markets, 10(1), 73-88.

Gegez, A. E. (2007). Pazarlama Araştırmaları. İstanbul: Beta Basım Yayım Dağıtım.

Göktaş, B. (2019). Tüketicilerin Kendi İllerine Ait Markalar Hakkında Görüşlerine Yönelik Tüketici Etnosentrizm Temelli Bir Araştırma: Tokat Markaları Örneği. Stratejik ve Sosyal Araştırmalar Dergisi, 3(2), 257-275.

Gürbüz, S. ve Şahin, F. (2017), “Sosyal Bilimlerde Araştırma Yöntemleri”, Ankara: Seçkin Yayıncılık. 
Han, C. M. (1988). "The Role of Consumer Patriotism in the Choice of Domestic Versus Foreign Products," Journal of Advertising Research, 28(June/July), 25-31.

Han, C. M. (1989). “Country Image: Halo or Summary Construct”, Journal of Marketing Research, 26(May), 222-229.

Hayes, F. A. (2013). Introduction To Mediation, Moderation And Conditional Process Analysis, New York: The Guilford Press.

Hong, S.-T. ve Wyer, Jr. R. S. (1989), "Effects of Country-of-Origin and Product-Attribute Information on Product Evaluation: An Information Processing Perspective," Journal ofConsumer Research, 16(September), 175-87.

İzmir, O. (2017). Satın Alma Niyeti Oluşturmada Menşe Ülke İmajının Tüketicinin Aşinalık Durumuna Göre Direkt Ya Da Dolaylı Etkileri: Hale Etkisi vs. Özet Yapı. Gümüşhane Üniversitesi Sosyal Bilimler Enstitüsü Elektronik Dergisi, 8(21), 131-147.

Jaworski S. P. ve Fosher, D. (2003) "National Brand Identity \& Its Effect on Corporate Brands: The Nation Brand Effect (NBE) ", The Multinational Business Review, 11 (2), 99-113.

Jenes, B. (2005): Possibilities of Shaping Country Image. Marketing és Menedzsment, 2, 18-29.

Kaynak, E. ve Kara, A. (2002) "Consumer Perceptions of Foreign Products: An Analysis of Product Country Images and Ethnocentrism", European Journal of Marketing, 36(7/8), 928-949.

Keskin, H. D. ve Yıldız, S. (2010). Tüketicilerin Marka Tercihlerinde Etkili Olan Faktörler ile Marka İmajı'nın Marka Değeri Üzerindeki Etkileri: Trabzon Örneği. Dumlupınar Üniversitesi Sosyal Bilimler Dergisi. Say1.27, 239-254.

Klein, J. G., Ettenson, R. ve Morris, M. D. (1998). The Animosity Model of Foreign Product Purchase: An Empirical Test in the People's Republic of China. Journal of Marketing, 62, 89-100.

Klopf, D.W. 2001. Intercultural Encounters: The Fundamentals of Intercultural Communication. Third Edition, Englewood: Morton.

Kotler, P., Haider, D. ve Rein, I. (1993): Marketing Places: Attracting Investment and Tourism to Cities, States and Nations, The Free Press.

Kotler, P. Jatusripitak, S. ve Maesincee S. (2000). Ulusların Pazarlanması, (Çev. Ahmet Buğdaycı), İstanbul: Türkiye İş Bankası Kültür Yayınları.

Koubaa, Y. (2008). Country of Origin, Brand Image Perception, and Brand Image Structure. Asia Pacific Journal of Marketing and Logistics, 20(2), 139-155.

Kwak, H., Jaju, A. ve Larsen, T. (2006). Consumer Ethnocentrism Offline and Online: The Mediating Role of Marketing Efforts and Personality Traits in The United States, South Korea and India, Journal of the Academy of Marketing Science, 34(3), 367-385.

Lala, V., Allred, A. T. ve Chakraborty, G. (2009) "A Multidimensional Scale for Measuring Country Image", Journal of International Consumer Marketing, 21(1): 51-66.

Lantz, G. ve Loeb, S. (1996). Country of Origin And Ethnocentrism: An Analysis of Canadian and American Preferences Using Social Identity Theory. Advances in Consumer Research, 23(23), 374-378.

Laroche, M., Papadopoulos, N., Heslop, L. A. ve Mourali, M. (2005). The Influence of Country Image Structure on Consumer Evaluations of Foreign Products, International Marketing Review , 22(1), 96-115.

Luque-Martinez, T., Ibáñez-Zapata, J.A. ve Salvador Del B.G. (2000). Consumer Ethnocentrism Measurement: An Assessment of The Reliability and Validity of The Cetscale in Spain. European Journal of Marketing, 34(11/12), 1353-1373.

MacCallum, R. C., Widaman, K. F., Preacher, K. J. ve Hong, S. (2001), “Sample Size in Factor Analysis: The Role Of Model Error", Multivariate Behavioral Research, 36(4), 611-637.

Maheswaran, Durauraj (1994), "Country-of-Origin as a Stereotype: Effects of Consumer Expertise and Attribute Strength on Product Evaluations," Journal ofConsumer Research, 21 (September), 354-365.

Martin, I. M. ve Eroglu, S. (1993). Measuring A Multi-Dimensional Construct: Country Image, Journal of Business Research, 28(3), 191-210. 
Mutlu, H. M., Çeviker, A. ve Çirkin, Z. (2011). Tüketici Etnosentrizmi ve Yabancı Ürün Satın Alma Niyeti: Türkiye ve Suriye Üzerine Karşılaştırmalı Analiz. Sosyo Ekonomi, 1, 52-73.

Nagashima, A. (1970) "A Comparison of Japanese and U.S. Attitudes Toward Foreign Products", Journal of Marketing, 34(1): 68-74.

Özenç H (2002) Türkiye'nin İmaj Sorunu ve İhracat, Kalder Forum, 2(8), 38-44.

Öter, Z. ve Özdoğan, O. N., (2005). Kültür Amaçlı Seyahat Eden Turistlerde Destinasyon İmajı: Selçuk-Efes Örneği. Anatolia: Turizm Araştırmaları Dergisi, 16(2), 127-138.

Özdemir, E. K, Güzeloğlu, E. B. ve Topsümer, F. (2018). Tüketici Etnosentrizmi, Marka Kişiliği Algısı ve Satın Alma Niyeti Arasındaki İlişkinin Değerlendirilmesi: Türkiye'deki Beyaz Eşya Markalarına Yönelik Bir Uygulama. Global Media Journal TR Edition, 8(16), 354-372.

Öztürk, S. A., Doğan Çifçi, S., Abbas, M., Ögel, S. ve Gümüş, C. (2017). Bilmek mi Sevmek mi? Bilişsel ve Duygusal Ülke İmajının Ürün İmajı ve Satın Alma Niyeti Üzerindeki Etkisi Üzerine Kültürler Arası Bir Çalışma (Araştırma). Pazarlama ve Pazarlama Araştırmaları Dergisi, 19, 79-102.

Öztürk, S. A., Özata, F. Z. ve Erol, F. (2019). “Tüketici Düşmanlığının Ülke İmajı, Ürün Değerlendirme ve Yabancı Ürün Satın Alma İsteğine Etkisi Üzerine Bir Araştırma", İstanbul Gelişim Üniversitesi Sosyal Bilimler Dergisi, 6 (1), 76-101.

Papadopoulos, N (2004) "Place Branding: Evolution, Meaning and Implications", Place Branding, $1(1), 36-49$.

Papadopoulos, N. ve Heslop, L. A. (1993). "Product-Country Images: Impact and Role in International Marketing", New York: International Business Press.

Park, S. B. R., Kim, M. J. ve Choi, J. S. A (2014). "Redevelopment of Country Image Scale Questionnaire", Net Journal of Social Sciences, 2(2), 53-59.

Preacher, K.J. ve Hayes, A.F. (2008). “Asymptotic and Resampling Strategies For Assessing and Comparing Indirect Effects in Multiple Mediator Models", Behavior Research Methods, 40, 879_ 891.

Reardon, J., Miller, C., Vida, I. ve Kim, I. (2005) The Effects of Ethnocentrism and Economic Development on The Formation of Brand and Ad Attitudes in Transitional Economies, European Journal of Marketing, 39(7/8), 737-754.

Reutter, K. K. ve Bigatti, S. M. (2014), "Religiosity and Spirituality as Resiliency Resources: Moderation, Mediation, or Moderated Mediation?", Journal for the Scientific Study of Religion, 53(1), 56-72.

Roth, K. P. ve Diamantopoulos, A. (2009). Advancing The Country Image Construct. Journal of Business Research, 62(7), 726-740.

Shimp, T.A. and S. Sharma (1987). Consumer Ethnocentrism: Construction and Validation of the CETSCALE, Journal of Marketing Research, 24, 280-289.

Sumner W. G. (1906). Folkways: A study of the Sociological Importance of Usages, Manners, Customs, Mores and Morals. Boston: Ginn and Company.

Supphellen, M., Grønhaug, K. (2003). Building Foreign Brand Personalities in Russia: The Moderating Effect of Consumer Ethnocentrism. International Journal of Advertising, 22 (2), 203226.

Tabachnick, B. G. ve Fidell, L. S. (1996), Using Multivariate Statistics. New York: Harper Collins Publication.

Torres, N. H. J. ve Gutierrez, S. S. M. (2007). “The Purchase of Foreign Products: The role of Firm's Country-of-origin Reputation, Consumer Ethnocentrism, Animosity and Trust", Universidad de Burgos, Documento de Trabajo, 13, 1-34.

Tuncer, M. A. ve Gökşen, H. (2016). İçecek Sektöründe Tüketici Etnosentrizmi: Türkiye-Hollanda Karşılaştırmalı Uygulaması. International Review of Economics and Management, 4(1), 67-95.

Uğur ve Sarığlu Uğur (2019). Tüketici Şüpheciliğinde Etnosentrizm Etkisi. Business \& Management Studies: An International Journal, 7(3), 1-13.

Uyar K. ve Dursun Y. (2015) Farklı Ürün Kategorilerinde Yabancı Markalama ve Tüketici Etnosentrizmi. Atatürk Üniversitesi Sosyal Bilimler Enstitüsü Dergisi, 19(2), 363-382. 
Ülker Demirel, E. (2020). Ülke İmajının Satın Alma İstekliliği Üzerindeki Etkisinde Tüketici Yakınlığı, Ürün Ülke İmajı ve Ürün Yargılarının Aracılık Rolü. İşletme Araştırmaları Dergisi, 12(2), 1225-1238.

Wang, C. L., Li, D., Barnes, B. R. ve Ahn, J. (2012). Country Image, Product Image and Consumer Purchase Intention: Evidence From An Emerging Economy, International Business Review, 21(6), 1041-1051.

Watson J. J. ve Wright, K. (2000). Consumer Ethnocentrism and Attitudes Toward Domestic and Foreign Products, European Journal of Marketing, 34(9/10), 1149-1166.

Vida, I. ve Reardon, J. (2008). “Domestic Consumption: Rational, Affective or Normative Choice", Journal of Consumer Marketing, 25(1), 34-44.

Xin, L. ve Seo, S.(S). (2020). The Role of Consumer Ethnocentrism, Country Image, and Subjective Knowledge in Predicting Intention to Purchase Imported Functional Foods. British Food Journal, 122(2), 448-464.

Yasin, N. M., Noor, M. N. ve Mohamad, O. (2007). Does image of Country-of-Origin Matter to Brand Equity?, Journal of Product and Brand Management, 16(1), 38-48.

Yazıcıoğlu, Y. ve Erdoğan, S. (2004). SPSS Uygulamalı Bilimsel Araştırma Yöntemleri, Ankara: Detay Yayıncılık.

Yıldız, E. ve Koçan, M. (2019). Tüketici Etnosentrizmi, Algılanan Kalite ve Marka Sadakatinin Marka Kişiliği Üzerindeki Etkisi: Krem Çikolata Tüketicileri Üzerine Bir Uygulama. Bingöl Üniversitesi Sosyal Bilimler Enstitüsü Dergisi, 9(17), 309-326.

Yue, M. L., Thwaites. D. ve Pillai, K. G. (2014). Effectiveness of Olympic Sponsorship by Foreign and Domestic Companies: The Influential Role of Consumer Ethnocentrism. International Journal of Sports Marketing \& Sponsorship, 15(2), 107-123.

\section{Aim and Scope}

\section{Extended Abstract}

Some consumers may act emotionally while making a purchase decision. While making a purchase decision, they consider whether the product they will buy is domestic or foreign, rather than factors such as quality, price and benefit. Such consumers think that buying foreign products harms their country, so they think that domestic products should be purchased. However, this thought of consumers is also affected by some factors. The level of ethnocentrism may be lower if the image of the country in question on consumers is positive or if the consumers have positive thoughts about the products of that country. . The main purpose of this research is to examine the effects of country of origin image on ethnocentrism, product judgment and willingness to purchase foreign products.

\section{Methods}

Convenience sampling method, one of the non-random sampling methods, was used in the study. The reason for this is that there are difficulties in reaching the participants due to the covid 19 pandemic, which affects the whole world. Convenience sampling method was used in order to minimize these problems and reach as many participants as possible. In addition, since it was not possible to conduct a face-to-face survey due to the pandemic, an online survey was applied to the participants. After the preliminary control was done by two academicians who are experts in their fields, the questionnaire was applied to 407 people between 01.07.2021 and 01.08.2021. 11 of the collected survey data were excluded from the analysis because it was determined that they were not filled properly. Considered 396 data were analyzed in SPSS 21 program. Hayes (2013) states that the use of Structural Equation Modeling in studies with more than one mediator variable is insufficient to determine the mediating effect. Since the research has two mediating variables, ethnocentrism and product judgment, the Process program was used to determine the mediating effect.

\section{Findings}

As a result of the analysis, it has been determined that the country image has a positive effect on the willingness to purchase foreign products and product judgments. Country image also has a negative impact on consumer ethnocentrism. Consumer ethnocentrism has a negative effect on the 
willingness to buy foreign products. Product judgments have a positive effect on the willingness to purchase foreign products. Consumer ethnocentrism and product judgments have a partial mediating role in the relationship between country image and willingness to purchase foreign products.

\section{Conclusion}

When consumers have positive thoughts about the image of a foreign country, their ethnocentric tendencies decrease, their thoughts about that country's products are more positive and their willingness to buy the products of that country increases. When the thoughts of the consumers about the products of the foreign country are positive, their willingness to buy the products of that country increases. As consumers' ethnocentric tendencies increase, their willingness to purchase foreign products decreases. For this reason, it will be effective for businesses operating in international markets to establish the perception that they are from that country, serve that country, know their culture and be respectful in the country they operate in, increase their sales or not be affected by ethnocentric attitudes. 